\title{
Campus Management System
}

\section{DOI 10.1007/s12599-010-0105-9}

\section{The Authors}

Prof. Dr. Rainer Alt $(\bowtie)$

Information Systems Institute

University of Leipzig

Grimmaische Straße 12

04109 Leipzig

Germany

rainer.alt@uni-leipzig.de

\author{
Dr. Gunnar Auth \\ Director University Computing \\ Center \\ University of Leipzig \\ Neumarkt 9-19 \\ 04109 Leipzig \\ Germany \\ gunnar.auth@uni-leipzig.de \\ Received: 2010-02-17 \\ Accepted: 2010-03-11 \\ Accepted after two revisions by \\ Prof. Dr. Sinz. \\ Published online: 2010-04-27
}

This article is also available in German in print and via http://www. wirtschaftsinformatik.de: Alt R, Auth G (2010) Campus-Management-System. WIRTSCHAFTSINFORMATIK. doi: 10.1007/s11576-010-0224-4.

(c) Gabler Verlag 2010

\section{Motivation}

In recent years, integrated application systems became generally known in the sector of higher education as campus management systems (CMS). The focus is similar to concepts that have proven to be effective for integrated information management within companies in the form of enterprise resource planning (ERP) or merchandise planning and control systems: Data integration using a common database, integration of functions by avoiding redundant functions, and process integration by implementation of cross-functional activity flows. In connection with the diffusion of both Internet access and portal concepts an increasing importance of service has evolved. Accordingly, webbased self-service features support students, teachers, and others in performing their tasks (Pollock 2003). The overall goal in designing and implementing an integrated CMS is to advance both the efficiency and the effectiveness of the entire study organization, and as a consequence, improving the quality of teaching and learning. From the perspective of the university, the most important exogenous drivers for the emergence of CMS include:

1. The Bologna Process (an agreement among European governments on the unification of higher education), which added a significant amount of administrative work regarding the organization of courses and examinations. In particular, medium-sized and large universities are no longer able to handle the complexity of module combinations, the registrations of modules in several programs, or the calculations of credit points without any support of database application systems (Schilbach et al. 2009). As a result, the German Rectors' Conference has recommended the universities to use suitable software, consistent with the objectives and instruments of the Bologna process (n. a. 2009). Furthermore, integrated application systems will avoid the known shortcomings of isolated solutions.

2. Universities face an increasing competition for students, academics and financial resources in both the national and the international context. Therefore, they need to improve the quality of both their services as well as their service delivery, for example within the framework of the Excellence Initiative of the German federal and state governments. In particular, future generations of students, who grew up in the Internet age, take electronic services such as e-learning or self-service for granted. Universities try to meet this demand by pursuing "eScience" strategies that aim to support all scientific fields and activities with new electronic media. According to Igel $(2007$, p. 70$)$, this development will change both the internal and the external perception of higher education more fundamentally than many previously enacted laws and regulations.

3. In analogy to other industries standard software packages have emerged for the consistent support of higher education processes. They replace proprietary software which was developed for specific functional areas of higher education only. Commercial providers now offer a solution to a variety of users with the same or similar requirements. On the one hand this leads to more professional software development and maintenance processes, but on the other also to an increased dependency from the solution providers and the necessity to adapt the software to the individual university structures. Although a number of universities are currently replacing their existing systems by a CMS (Schilbach et al. 2009), the sector of higher education is only at the beginning, especially when compared to other industries.

The identified drivers initially point to the well-known interaction between organizational and technological design: Integrated application systems are enablers of change for organizational structures in higher education whose design, in turn, determines the system's benefits. Thus, a CMS implementation is not only a challenge for technological realization but also for the modification of the entire organizational system "university".

\section{Definition of Concept}

The notion of CMS has spread in the German-speaking world in recent years only and links to older concepts, such as academic information systems (IS). Like these systems, CMS aim at a broad support of all university processes. The university can be conceived as service provider that serves cross-functional and interdepartmental processes, recognizes students as customers, and provides the means to help for self-help (Küpper and Sinz 1998, p. 3 f.). The goals are similar to those of ERP systems, i.e., the companywide application of modularized systems 
that use a centralized database and a single user interface to improve the support of an organization's business processes.

Similar to the heterogeneous definition of ERP systems, different CMS approaches suggest that an agreed-upon understanding of terms is still missing. Nevertheless, three characteristics have emerged for CMS: (1) A CMS follows the principles of integrated application systems, which, for instance, include a single point of data entry, a single database and user interface, the real-time access to information as well as the support of crossfunctional processes. (2) Compared to academic or university IS created as individual software, CMS are specifically designed as standard software, which is modularized and customizable. If necessary, individual requirements can be met by additional programming. (3) From a functional point of view, CMS cover all operational (horizontal integration) as well as all business intelligence (vertical integration) functionalities in higher education (Brune et al. 2009, p. 486). In both literature and practice two views regarding the functionality may be observed:

1. In a narrower sense, CMS comprise functionalities for managing teaching and learning. Thus, many vendors enhance their ERP portfolio with CMS. These systems focus on supporting the so-called student life cycle. This includes in particular functions for application and enrollment, student records, and managing courses, evaluations, and alumni relationships.

2. In a broader sense, CMS offer electronic support not only in the areas of teaching and learning management but also in research and resource management (e.g., human resources and accounting) as well as teaching itself (e-learning). Therefore, they aim at "a comprehensive, web-based mapping of the important elements of a university system and its specific functional relationships, and allow a participatory integration of system elements" (Bieletzke and Beise 2009, p. 4; translated into English).
In fact, a functional perspective yields many interdependencies between the management of teaching and learning and the management of resources. The academic staff, for instance, typically comprises both teaching and research staff. Therefore, efforts have emerged in literature and practice to link academic learning platforms and the software for managing a university's administrative functions (e.g., Bucksch et al. 2008).

\section{Major Vendors and Functionality}

Currently, many German universities are engaged in implementing or enhancing application systems that can be considered as CMS. Some universities act as providers and offer licenses for their self-developed applications to other universities, such as Bamberg University's module and exam management system FlexNow! ${ }^{1}$ or CampusOnline ${ }^{2}$ developed by the Technical University of Graz. Although individually developed systems still dominate, the diffusion of commercial standard software is widely expected (Bick and Börgmann 2009). Almost from the early days of information technology in higher education, the software and consulting company HIS HochschulInformations-System $\mathrm{GmbH}^{3}$ dominated the German market. But since the mid1990s, new vendors entered the market at a rapid pace. These include SAP $A G{ }^{4}$ the Datenlotsen Informationssysteme $A G^{5}$ or CAS Software GmbH. ${ }^{6}$ More recent examples are open source products, such as Kuali Student ${ }^{7}$, which is jointly developed by several U.S. universities.

To characterize the functionality of CMS various categorizations along the customer processes were suggested. In particular, the model of the so-called "student life cycle" may be linked to the concept of customer orientation. While this has become a well-known strategy for commercial organizations, the sector of higher education is often attributed an exceptional nature due to the non-economic goals of teaching and research (e.g., Meinert 2007). CMS, feature customer orientation primarily in supporting the interactions of a university with its external stakeholders (students, alumni, etc.) and the widest possible support for the underlying activities.

Obviously, the student life cycle is based on the customer life cycle model known from marketing and customer relationship management. Both serve to structure the complex interfaces to the customer (respectively student) and the systematic identification of IT-based potential for improvement. Accordingly, the notion of "Student Relationship Management" (SRM) may be found (Hilbert et al. 2007), which explicitly conceives the student as a customer for the service "academic education". Furthermore, SRM focuses on strengthening the relationship between students and their university. This starts with the orientation and recruitment prior to enrollment, and includes all activities while attending academic programs, literally until the end of life (alumni management). During that process, the intensity of the relationship between students and the university varies over time. In the approach phase, prospective students are looking for suitable programs and university. This phase ends with the enrollmenties and leads to the socialization phase with the beginning of the courses. Before entering the growth phase, a hazardous phase, denotes the possibility that students discontinue or change universities. The growth phase usually ends with a professional qualification and the entry into working life which characterizes the abstinence phase. Following the idea of lifelong learning there may be reactivation phases in which the graduate returns to pursue postgraduate studies. Thus, the student life cycle leads to the following key features of CMS:

1. Student administration to store and process personal data of students for functions, such as application, admission, enrollment, or fee management up to alumni services.

2. Course management for the administration of examination regulations, module data and catalogs, as well as production of module handbooks and curricula.

\footnotetext{
${ }^{1}$ http://flexnow.uni-bamberg.de/.

${ }^{2} \mathrm{https} / / /$ online.tu-graz.ac.at/.

${ }^{3} \mathrm{http}: / /$ www.his.de/.

${ }^{4} \mathrm{http}: / /$ www.sap.com/germany/industries/highered/index.epx.

${ }^{5} \mathrm{http}: / /$ www.datenlotsen.de/.

${ }^{6} \mathrm{http}: / /$ www.cas.de/Produkte/Campus/Campus_Home.asp.

${ }^{7}$ http://student.kuali.org/.
} 
3. Exam administration for planning, organization and documentation of examinations, schedules and results, and generation of certificates and testimonials.

4. Course planning including management of rooms, schedules and courses, the creation of electronic course catalogs as well as evaluation functions.

5. Reporting functions with business intelligence capabilities to support decision-makers at all levels with predefined reports as well as ad-hoc analyses of the CMS database.

6. Cross-departmental functions to ensure the integrated nature of the system, in particular document and identity management.

Most CMS products currently follow the narrow CMS definition. Only few CMS offer functionality in a broader sense, i.e., in the field of research and resource management as well as teaching. They focus on administrative functions for teaching and learning and provide only interfaces to learning management systems (LMS). LMS already exist independently at many universities and need to be closely integrated for consistently supporting the complete student life cycle according to the broader CMS definition. There are two fundamental architectural approaches to CMS implementation: integrating multiple, specialized (standard) application systems on the one hand, and the usage of a fully integrated (standard) application system on the other (Radenbach 2009).

\section{Conclusion}

After the introduction of self-developed proprietary application systems, CMS represent a 'second wave' of IS support in higher education. Being integrated standard software, CMS are a prerequisite for an efficient implementation of the Bologna Process at the operational level and for the advancement of higher education at the strategic level. CMS provide integrated functionality along the entire student life cycle and are vital to manage the increasingly complex and networked range of course offerings. They contribute to the professionalization of software development and maintenance, as well as to automation and re-design of business processes. However, the shape of CMS will evolve as will the sector of higher education. Among the possible future developments are:
1. From the perspective of the entire system of higher education, the increasing possibility of changing among programs of many institutions. Despite their traditional separation, classical universities, universities of applied sciences as well as cooperative education will increasingly exchange services among each other due to the Bologna reform. The same applies to universities outside Germany which in sum makes the inter-university exchange of data regarding modules, examinations, and students through standardized interfaces, such as those included in standard software, more important.

2. From the perspective of individual institutions, universities will continue to become more service-oriented to foster their competitive position in the academic "marketplace". The implementation of the service concept is supported by the evolving Service Science which, for examples, foresees the adoption of centralized service centers and desks, the definition of comprehensive customer processes which flexibly include the required services. Service-oriented architectures may be considered as important technological enablers for this development.

3. From the perspective of "classical" university computing centers, service orientation opens the view to new operational and business models. These may, for example, evolve to act as service providers to other - in particular smaller - universities in terms of business process outsourcing and offer the benefits of CMS as "Software as a Service" (e.g., Wannemacher et al. 2008, pp. 17 ff.). These developments are linked with the already widespread collaborations between universities in the IT sector, such as the joint operation of data centers (e.g., Leibniz-Rechenzentrum Munich, Germany) or application service provisioning.

4. From the perspective of CMS vendors, comprehensive solutions for all areas of the student life cycle and the university administration are relevant. Ideally, the components of the CMS solutions are not only interoperable within the reference models of each provider, but also between multiple vendor-specific platforms. Such interuniversity standard interfaces on a national and even international level, however, require a broad cooperation between vendors and academic organizations. Ultimately, given the budget constraints in many universities, the open source movement will also be important to consider in the CMS area (Panettieri 2008).

Similar to the experiences obtained in the ERP area, universities need to carefully assess the costs and the risks of a complex implementation when transforming their organization's operations. Thus, the introduction of CMS calls for the standardization of a university's services and business processes as well as data structures. Therefore, the cooperation among faculties and other previously highly autonomous organizational units is critical. Universities with experience in CMS implementation report that the major challenges are not within the technical but the organizational transformation (Janneck et al. 2009). Only the successful migration along these political, strategical, organizational, and technological dimensions, ultimately taps all potential benefits of a CMS.

\section{References}

Bick M, Börgmann K (2009) A reference model for the evaluation of information systems for an integrated campus management. EUNIS conference, Santiago de Compostela

Bieletzke S, Beise A (2009) Ganzheitlichkeit von Campus-Management-Systemen als Akkreditierungsvorteil. http://www. ecampus24.eu. Accessed 2010-02-15

Brune $H$, Jablonski $M$, Möhle V, Spitta T, Teßmer M (2009) Ein Campus-Management-System als evolutionäre Entwicklung. In: Hansen HR, Karagiannis D, Fill H-G (eds) Business Services: Konzepte, Technologien, Anwendungen. 9. Internationale Tagung Wirtschaftsinformatik. Österreichische Computergesellschaft, Wien, pp 483-492

Bucksch A, Müller F, Podehl E, Welchering $S$ (2008) Kopplung von Lernplattformen mit Hochschulverwaltungssoftware. Fachhochschule Köln

Hilbert A, Schönbrunn K, Schmode S (2007) Student relationship management in Germany - foundations and opportunities. Management Revue 18(2):204-219

Igel C (2007) Learning management on campus. Information Management \& Consulting 22(2):69-77

Janneck M, Fiammingo S, Melichar R, Adelberger C (2009) Von Eisbergen und Supertankern: Topologie eines CM-Einführungsprozesses. In: Hansen HR, Karagiannis D, Fill H-G (eds) Business Services: Konzepte, Technologien, Anwendungen. 9. Internationale Tagung Wirtschaftsinformatik. Österreichische Computergesellschaft, Wien, pp 453-462

Küpper H-U, Sinz E (eds) (1998) Gestaltungskonzepte für Hochschulen: Effizienz, Effektivität, Evolution. Schäffer-Poeschel, Stuttgart 
Meinert S (2007) Student gleich Kunde? In: Financial Times Deutschland. http://www. $\mathrm{ftd}$.de/karriere-management/karriere/: student-gleich-kunde/192021.html. Accessed 2010-02-12

na (2009) Entschließung der 5. (a.o.) Mitgliederversammlung. Zum BolognaProzess nach 2010. Hochschulrektorenkonferenz. Die Stimme der Hochschulen. http://www.hrk-bologna.de/bologna/de/ download/dateien/Entschliessung

Bologna\%281\%29.pdf. Accessed 201002-11
Panettieri JC (2008) Is open source the ERP cure-all? Campus Technology 21(9):30-35

Pollock N (2003) The 'self-service' student building enterprise-wide systems into universities. Prometheus 21(1):101-120

Radenbach W (2009) Integriertes Campus Management durch Verknüpfung spezialisierter Standardsoftware. In: Hansen HR, Karagiannis D, Fill H-G (eds) Business Services: Konzepte, Technologien, Anwendungen. 9. Internationale Tagung
Wirtschaftsinformatik. Österreichische Computergesellschaft, Wien, pp 503-512

Schilbach $\mathrm{H}$, Schönbrunn K, Strahringer S (2009) Off-the-shelf applications in higher education: a survey on systems deployed in Germany. In: Abramowicz W (ed) Business information systems. Springer, Heidelberg, pp 242-253

Wannemacher K, Moog H, Kleimann B (eds) (2008) ITIL goes university? Serviceorientiertes IT-Management an Hochschulen. HIS, Hannover 